\title{
EFFECT OF COWPEA SEED DRYING TEMPERATURE AND WET MILLING ON THE RHEOLOGICAL PROPERTIES OF MOIN-MOIN PASTE AND GEL
}

\author{
N. J. Enwere ${ }^{1}$ and $Y-C$. Hung ${ }^{2}$ \\ 'Department of flood Science and Technology \\ University of Nigeria, Nsukka \\ 'Department of Food Science and Technology \\ College of Agriculture and Environmental Sciences \\ Georgia Experimental Station, Griffin \\ The University of Georgia \\ Georgia 30223-1797 USA.
}

\begin{abstract}
The effects of cowpea seed drying temperature and wet-milling on the viscosity of moin-moin paste and texture (rheology) of moin-moin gel were studied. The large brown eye Kano white cowpea seeds were soaked in water at $25^{\circ} \mathrm{C}$ for $5 \mathrm{~min}$, drained and dried at temperatures between 30 and $120^{\circ} \mathrm{C}$, decorticated and dry milled imo flour: Decorticated cowpea seeds dried at $30^{\circ} \mathrm{C}$ were soaked in cold water at $25^{\prime \prime} \mathrm{C}$ for $1.5 \mathrm{hr}$ and wet milled into paste. The cowpea flours and paste were reconstituted with water and prepared into moin-moin with and without addition of salt, pepper, tomato paste, onions, vegetable oil and beefflavon: Determination of the moln-moln paste viscosity prior to steaming showed that all the pastes exhibited pseudoplastic flow behaviour. The moin-moin from the wet milled paste had higher viscosity than the samples from flours due to higher, swelling of the starch, protein and cell wall materials. The moin-moin pastes containing additional ingredients had higher viscosity than the plain samples due to the additional solid matter. Drying at temperatures between 80 and $120^{\prime \prime} \mathrm{C}$ increased the viscosity of the plain moin-moin paste but decreased those of samples with added ingredients. Texture studies showed that drying temperature, wet milling and addition of ingredients decreased the hardness of the moin-moin gel at 50\% double compression and relaxation.
\end{abstract}

Key words: Cowpea, moin-moin, viscosity, and texture

\section{Introduction}

Cowpea seed is a well-known legume consumed in Nigeria and ollier parts of the world. Its nutritional significance is derived from its high protein content between 21 and 28\% (Enwere, 1998). Cowpea seed is unique as food because il enn be prepared into different dishes (Dovlo. et al. 1976). The immature pods and seeds can be cooked and eaten as vegetable. Extract from the dry mature seed can be used to prepare substrate for natto. The mature cowpea seed can be converted into flour or paste used for moinmoin and akara preparation and for soup thickening. The cowpea flour has also been used in composite flour with wheat flour for cake and doughnut preparations. Various studies have been conducted on the properties of cowpea flour, paste, akara, moin-moin and seed (McWatiers and Brantley, 1982; MeWallers, 1993 and linwere 1985).

Aecording to Tinwere, of al. (1998), drying of wetted cowpea seeds at $30^{\circ} \mathrm{C}$ prior to decortication had no effect on the properties of the protein, starch and seed microstructure. Drying the welted cowpea seeds at $80^{\circ} \mathrm{C}$ adversely affected the albumins of the water-soluble protein to a fair degree while drying at $120^{\circ} \mathrm{C}$ extremely denatured the albumin in the water-soluble proteins 
and coused the akera prepared from the flour to loose its sponginess and become compact. 'The starch gramules also sulfered thermal damage as observed under scanning electron microscope examination. Different seed drying temperatures, especially, at elevated temperatures of 100 and $120^{\circ} \mathrm{C}$ adversely affected the sensory properties of akara and moin-moin. Viscosity and texture, which are rheological properties, have also been used by various workers to characterise foods (Enwere and Ngoddy, 1986).

The objective of this study, therefore, was to determine the effect of cowpea seed drying temperatures and wet milling on the viscosity and texture of moin-moin paste and gel, respectively, using objective theological instruments.

\section{Materials and Methods}

\section{Cowpea seed sample}

The large brown eye Kano white variety of cowpea seed (Vigna unguiculata) used in this study was purchased from the Nsukka market in December, soon after harvest.

\section{Proximate analysis}

The crude protein, moisture, crude fat, crude fibre and ash of the cowpea flour were determined according to AOAC (1984) method. Carbohydrate was determined by difference.

\section{Cowpea flour preparation}

The large brown eye Kano white cowpen seeds were prepared into flour according to the method, described by Enwere (1998). The wetted seeds were dried nt temperntures of 30, 60. 80,100 and $120^{\circ} \mathrm{C}$ prior to flour preparation.

\section{Preparation of wot milled paste}

Fresh cowpea paste was prepared immediately before use. In this method, $101.25 \mathrm{~g}$ of decorticated cowpea seed cotyledons dried at $30^{\circ} \mathrm{C}$ wore soaked in 1 litre of water at $25^{\circ} \mathrm{C}$ for $1.5 \mathrm{hr}$. It was drained, weighed and wet-milled into paste by blending for 2 min in an Oster Kitchen Centre blender (Model 965-041; Oster Corp.\}, with addition of more water to increase the sum of absorbed and added water to $300 \mathrm{ml}$.
Table 1: Recipe for moin-moin preparation

\begin{tabular}{|c|c|c|}
\hline \multirow[t]{2}{*}{ Ingredients } & \multicolumn{2}{|c|}{ Quantity in moin-moin } \\
\hline & Plain & $\begin{array}{l}\text { With additional } \\
\text { ingredients }\end{array}$ \\
\hline Cowpea flour & 33.75 & $33.75 \mathrm{~g}$ \\
\hline Red pepper (dry) & - & $0.1 \mathrm{~g}$ \\
\hline Onlon (liesli gronud) & - & $7.0 \mathrm{~g}$ \\
\hline Tomato paste & - & $7.0 \mathrm{~g}$ \\
\hline Meal lawour & - & $0.3 \mathrm{~g}$ \\
\hline Sull & . & 2,09 \\
\hline (irotndnut oil & - & $|0,0 \mathrm{me}|$ \\
\hline Water (at $70^{\prime \prime} \mathrm{C}$ ) & $100.0 \mathrm{ml}$ & $100.0 \mathrm{ml}$ \\
\hline
\end{tabular}

\section{moin paste and gel preparation}

The method described by linwere ef al. (19\%)) was used for moin-moin preparation. The recipe is given in Table 1. Two types of moin-moin pastes were prepared from the wet- milled cowpea paste and live flour samples obtained from cowpea seeds dried at $30,60,80,100$ and $1200^{\circ} \mathrm{C}$. The lirst type was, prepared witl water and cowpea flour (plain) and the second type was prepared with cowpea flour, and addition of the other ingredients including salt, pepper, tomato paste, onions, beef flavour and vegetable oil. The moinmoin paste was dispensed into aluminimm container (about 310-mi capacity), wilh internal diameter of $9.2 \mathrm{~cm}$ and depth of $5.2 \mathrm{~cm}$. It was covered with a fitting lid, steamed in a doubledecked steamer for $20 \mathrm{~min}$ and cooled for $2 \mathrm{hr}$ at $4^{\mathrm{A}} \mathrm{C}$ prior to texture measurement.

\section{Determination of moln-moln paste vlscos- ity}

The viscosity of the raw moin-moin paste was determined belore cooking. using a Brookliels rotational viscometer with a small sample adapter and spindle No 27 (Model IIAT, Brookfield Engineering Laboratories Inc, Stoughton, $M \Lambda$, USA). Measurements were taken at speeds of $0.5,1.0,2.5,5.0,10.0,20.0,50.0$ and $100 \mathrm{rpm}$, which correspond to shear rates of $0.17,0.34$, $0.85,1.7,3.4,6.8,17.0$ and $34.0 \mathrm{~s}^{-1}$, as calibrated by the viscometer manufacture.

\section{Measurement of moin-moln texture}

A combination of the methods of lsourne and Comslock (1981) and Ossai, et al. (1987) 
described by Enwere, er al. (1990) was used for texture measurement. In this study $1 \mathrm{~cm}^{3}(1 \times 1 \times$ $1 \mathrm{cmi})$ specimens were cut from the moin-moin samples with the ald of a metal grid and a sharp knife. The moin-moin cubes were subjected to

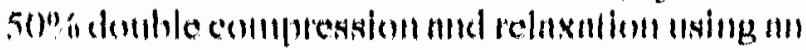
Instron Universal Texture Testing Machine (Model 1122, Instron Inc. Canton MA, USA). The Instron was fitted with a compression anvil 5.7-cm diameter and $50 \mathrm{~kg}$ load cell. It was operated with a crosshead speed of $10 \mathrm{~mm}$ per min. and a chart speed of $100 \mathrm{~mm}$ per min. Twelve measurements were made for each sample.

\section{Data analysis}

The power-law mathematical equation of Holdsworth (1971) was fitted to the viscosity data after the shear stress was determined using the shear rates ( ) given by the manufacturer and the apparent viscosity values ( ) obtained from measurements in consonance with equations (1) and (2), below:

$$
\dot{\gamma}=\eta \dot{\gamma}
$$

where $\tau=$ shear stress (Pa. s)

$$
\begin{aligned}
\tau=\eta \dot{\gamma} & =\text { Apparent viscosity }\left(\mathrm{Pa} \cdot \mathrm{s}^{-1}\right) \\
\eta & =\text { Shear rate }\left(\mathrm{s}^{-1}\right)
\end{aligned}
$$

The Power-law mathematical equation was used to calculate the flow consistency values and flow behaviour indices using the Statistical Analysis System SAS (1985):

$$
\tau=\eta \dot{\gamma}=b \dot{\gamma}^{n} \quad \text { (Power-law mathematical }
$$

equation)

where

$$
\begin{aligned}
& b=\text { flow consistency value } \\
& \mathbf{n}=\text { flow behaviour index }
\end{aligned}
$$

The texture profile and mechanical properties of the moin-moin gel were obtained from the force-deformation curves (Fig. 3) as follows:

1) Hardness $=$ the highest peak force in the first compression cycle

2) Modulus of elasticity or deformability = the slope of the linear segment of the force-deformation curve during the first compression cycle
3) Cohesiveness = the ratio of the area of second compresslon cycle to that of the first.

The areas were oblained with the aid of $n$ digitizer altached to an IBM compuler. 'Ihe clillerences in the mean hardness, cohesiveness, and mululus of elusticity were culculnted usinth analysis of variance and Duncan's Multiple Range Test Procedure.

\section{Results and Discussion}

\section{Proximate composition}

The large brown eye Kano white cowpea seed used in this study contained $11.11 \%$ moisture, $23.38 \%$ protein, $1.29 \%$ crude fat, $3.1 \%$ crude fibre, $3.28 \%$ ash and $60.94 \%$ total carbohydrate. These values are similar to those reported by Purseglove (1991).

\section{Flow behaviour of moin-moin pastes}

Flow behaviour properties of the moin-moin pastes determined and reported in this study include apparent viscosity, shear stress, flow behaviour index (In) and flow consistency value (b).

\section{Apparent viscosity}

The trends of the apparent viscosity of moin-moin pastes at different shear rates are shown in Figure 1. It was observed that the viscosity of the moin-moin pastes decreased as shear rate increased. Onweluzo, et al. (1994), also observed this trend in their rheological study of flours from lesser-known legumes. The plain moin-moin pastes had low viscosity because the protein was not denatured and starch was not gelatinised so could not swell and cause thickening with resultant effect on viscosity. In addition, the larger flour particles partly sedimented out of the paste when left to stand. This increased viscosity at the level of the spindle. The rate of sedimentation increased as drying temperature increased. Consequently, the viscosity of the plain moin-moin paste increased as cowpea seed drying temperature increased.

The plain moin-moin paste prepared from the wet-milled cowpea had much higher viscosity at 
N. J. Fnwere and Y-C. Ilung
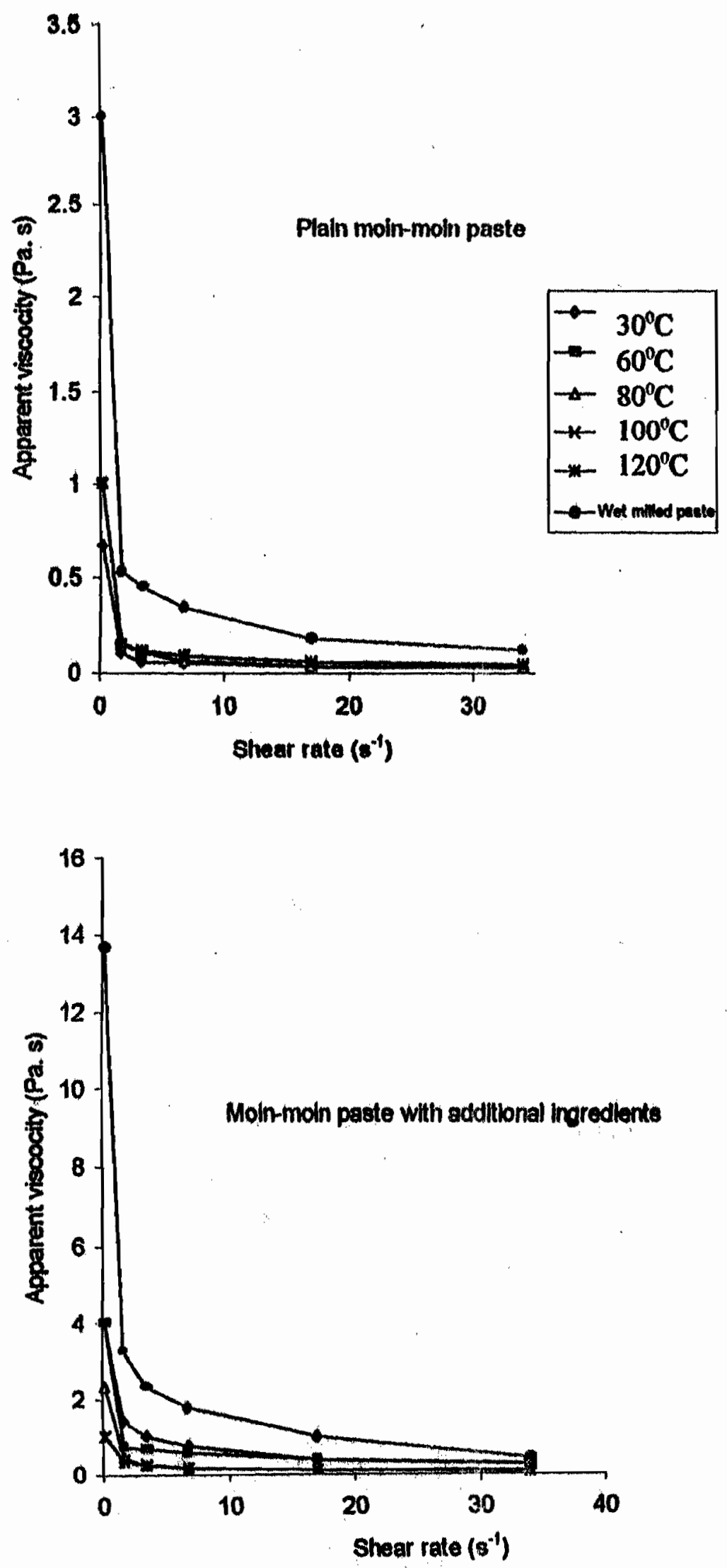

Fl. 1 Apparent viscoctly at different shiear rates of moin-moln pastes prepared with cowpea flour or wet-milled with or without additionat troredients 

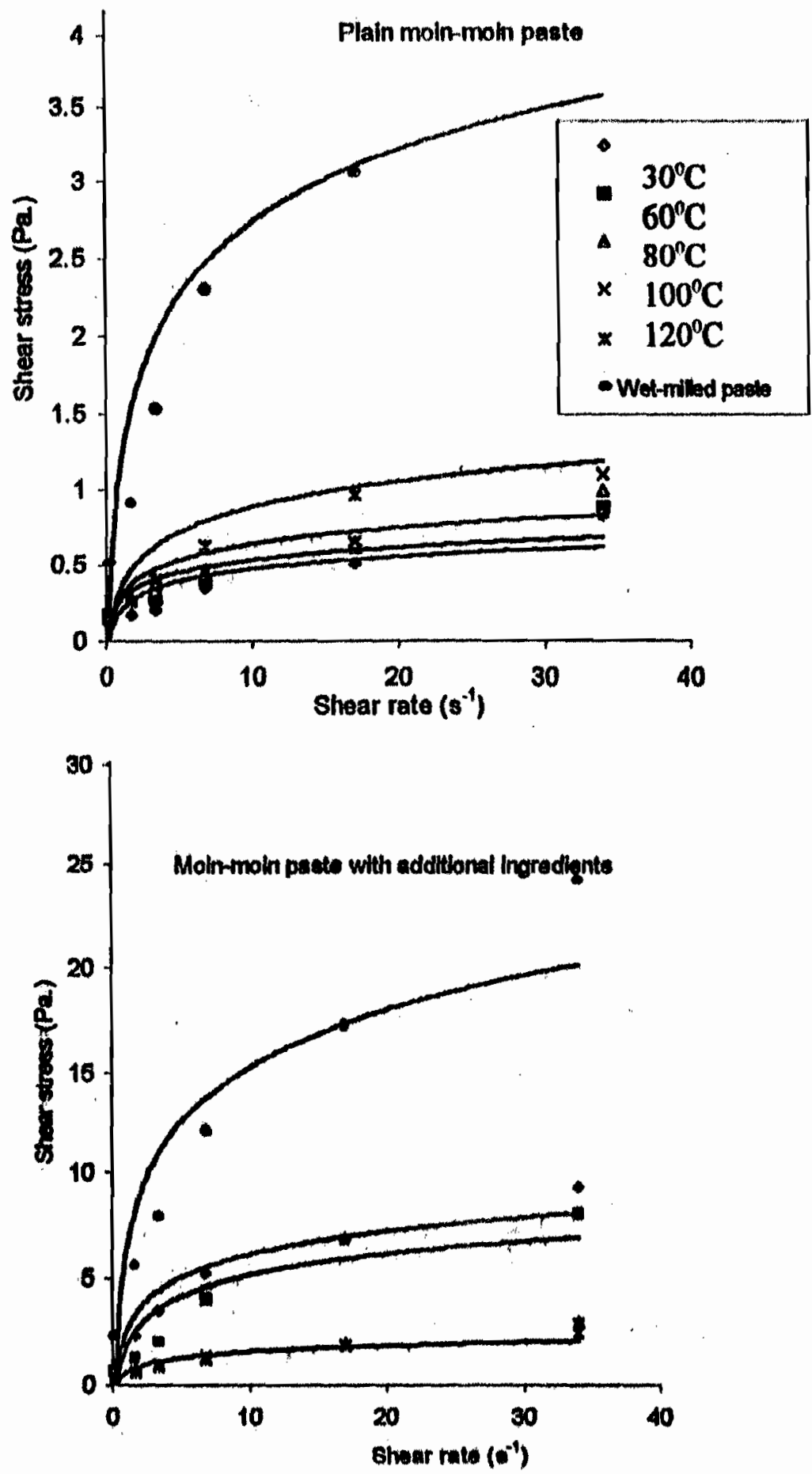

Fig. 2 Apparent vecoclty at different shaar rates of moin-moin pastes prepared with cowpea llour or wot-milliod with or without eddtitional maredionte 
N. J. Enwere and Y-C. Hung

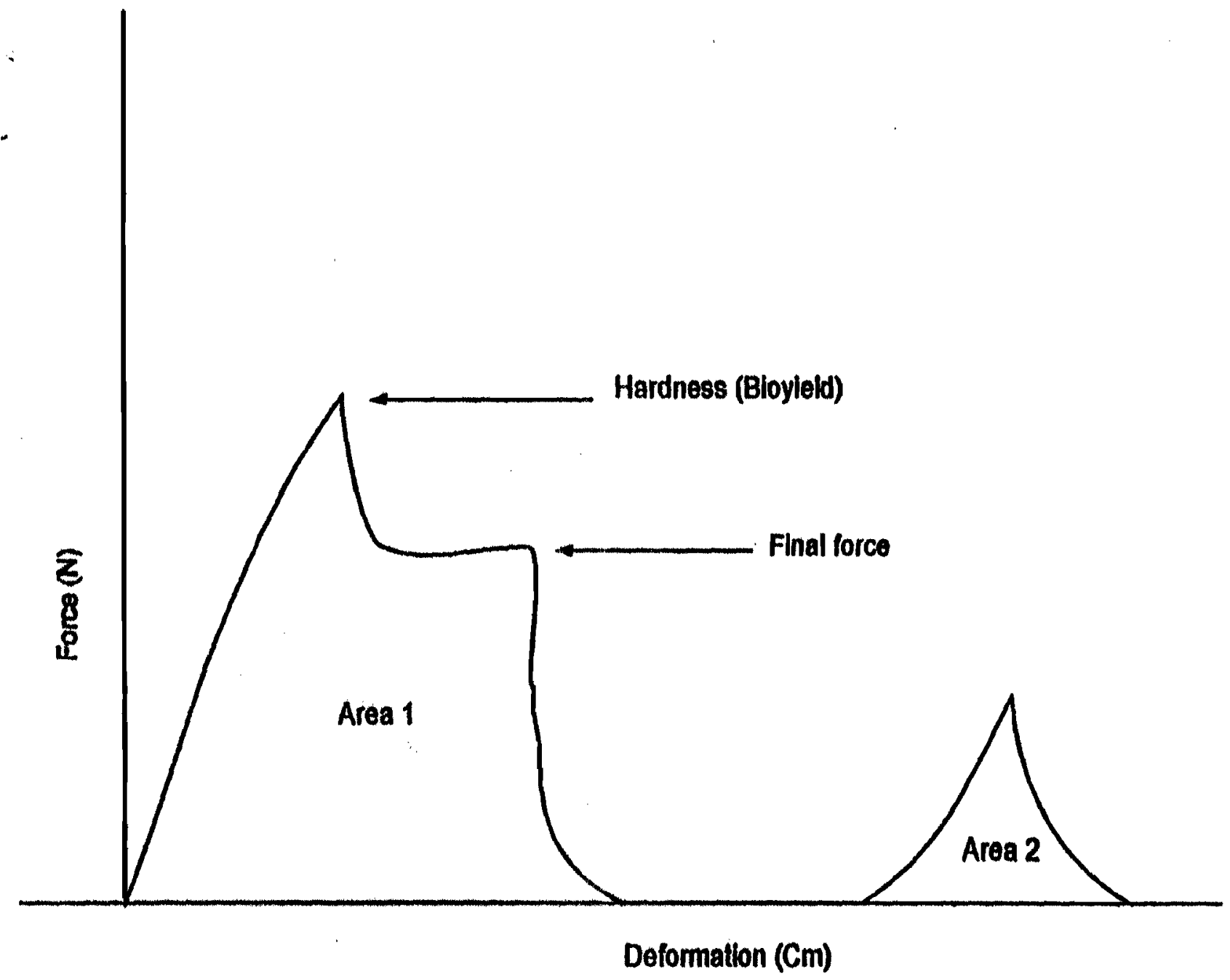

Fig. 3 A typical force-deformatlon curve at $50 \%$ compression level of moin-moin samples using a compression anvil fitted to the Instron Universal Texture Testing machine. 
all shear rates than the moin-moin pastes prepared from llour with and withoul additional inpredlents. Sonking and wet-filling lnerensed swelling of the cowpea components (protein, starch and cell wall materials), reduced mass density of the proteins and increased thickening and viscosity of the paste.

When pepper, tomato paste, onion puree, salt, beef flavour and vegetable oil were added to all the moin-moin pastes, viscosity increased substantially due to increased solid content or dry matter. The viscosity of the moin-moin pastes containing additional ingredients generally showed a reverse trend when compared with plain moin-moin pastes. It decreased as drying temperature increased because there was little sedimentation of particles around the spindle. The particles were more homogeneously distributed inside the paste such that the effect of thick- lesser-known tropical legumes. For all the moinmoin pastes, the shear stress increased as the shear rule also increased. 'The shear stress of the plain moin-moin pastes generally increased as the cowpea seed drying temperature increased. When ingredients were added, the trend was reversed. The shear stress values for the moin-moin prepared from the wet-milled cowpea paste was higher for the plain samples and the products containing all ingredients due to the of swelling of the cowpea seed particles during soaking, greater thickening and more particle-particle interaction.

\section{Power-law parameters}

The power-law parameters are the flow behaviour index (n) and the flow consistency value (b) given in Table 2. The flow behaviour index of all the moin-moin samples were less than one and greater than zero, depicting a

Table 2: Power-law parameters (flow behaviour index (n) and flow consistency value (b) of moin-moin pastes.

\begin{tabular}{ccccc}
\hline Sample & $\begin{array}{l}\text { Flow behaviours index }(\mathrm{n}) \\
\text { of moin-moin pastes }\end{array}$ & $\begin{array}{l}\text { Flow consistency value }(\mathrm{b}) \\
\text { of moin-moin pastes }\end{array}$ \\
\cline { 2 - 5 } & Plain & $\begin{array}{c}\text { With additional } \\
\text { ingredients }\end{array}$ & Plain & $\begin{array}{c}\text { With additional } \\
\text { ingredients }\end{array}$ \\
\hline Dried at $30^{\mathrm{O}} \mathrm{C}$ & $0.3392^{\mathrm{b}}$ & $0.5131^{\mathrm{a}}$ & $0.1864^{\mathrm{C}}$ & 0.5810 \\
$60^{\circ} \mathrm{C}$ & $0.2982^{\mathrm{b}}$ & $0.5080^{\mathrm{a}}$ & $0.2410^{\mathrm{bc}}$ & 0.7666 \\
$80^{\circ} \mathrm{C}$ & $0.3037^{\mathrm{b}}$ & $0.5132^{\mathrm{a}}$ & $0.2817^{\mathrm{b}}$ & 0.6510 \\
$100^{\circ} \mathrm{C}$ & $0.3118^{\mathrm{b}}$ & $0.5129^{\mathrm{n}}$ & $0.2707^{\mathrm{h}}$ & 0.4768 \\
$120^{\circ} \mathrm{C}$ & $0.4400^{\mathrm{a}}$ & $0.5151^{\mathrm{a}}$ & $0.2655^{\mathrm{b}}$ & 0.4234 \\
Wet-milled paste & $0.4343^{\mathrm{a}}$ & $0.3983^{\mathrm{b}}$ & $0.8822^{\mathrm{a}}$ & 4.6110 \\
\hline
\end{tabular}

lalues in the same columm not followed by the same lever a significamt at $p \leq 0.05$.

ening by additional ingredient mainly controlled the trend of viscosity. The tomato paste, dry pepper and onion puree, which were thick also, acted as viscosity enhancers, which prevented substantial particle sedimentation.

\section{Shear stress-shear rate relationships}

The shear stress-shear rate relationships of the moin-moin pastes are shown in Figure 2. Onweluzo, et al. (1994), also observed this relationship in their viscosity study of flours from pseudoplastic flow behaviour (Holdsworth (1971) and Uzoma and Ahiligwo (1995). The flow behaviour index of the plain moin-moin prepared with flour obtained from cowpeas dried at $120^{\circ} \mathrm{C}$ had higher value than the other samples prepared from flours but the differences were not significant. The plain moin-moin prepared from the wet milled cowpea paste had significantly higher flow behaviour index than samples from the flour. When other ingredients were added, the flow behaviour indices of all the moin-moin prepared from cowpea flour increased to almost 
Table 3: Texture profile parameters of moin-moin gel samples at $50 \%$ double compression and relaxation

\begin{tabular}{|c|c|c|c|c|}
\hline Type of snimple & 'Trentment & $\begin{array}{c}\text { Hurdiness } \\
\mathrm{N}\end{array}$ & Cohesiveness & $\begin{array}{l}\text { Finstic } \\
\text { modulus } \\
\mathrm{N} / \mathrm{cm}\end{array}$ \\
\hline \multirow{6}{*}{ Plnin } & $300^{n} \mathrm{C}$ & $0.8117^{1+}$ & $0.2775^{\circ}$ & $2.3341^{\prime \prime}$ \\
\hline & $60^{\circ} \mathrm{C}$ & $6.2236^{\mathrm{nh}}$ & $0.2226^{\prime \prime}$ & $2.5083^{n}$ \\
\hline & $80^{\circ} \mathrm{C}$ & $5.86 \mathrm{CH}^{\mathrm{h}}$ & $0.1902^{h}$ & $2.183,3^{\prime \prime}$ \\
\hline & $100^{\circ} \mathrm{C}$ & $5.0358^{b}$ & $0.2269^{\prime \prime}$ & $2.3167^{n}$ \\
\hline & $120^{\circ} \mathrm{C}$ & $5.3563^{\mathrm{b}}$ & $0.2362^{b}$ & $2.3917^{i \prime}$ \\
\hline & Wet-milled paste & $7.1286^{\mathrm{n}}$ & $0.2618^{11}$ & $2.5830^{\mathrm{n}}$ \\
\hline \multirow{6}{*}{$\begin{array}{l}\text { With additional } \\
\text { lngledlenls }\end{array}$} & $30^{\circ} \mathrm{C}$ & $4.2118^{n}$ & $0.25607^{n}$ & $0.6417^{n}$ \\
\hline & $60^{\circ} \mathrm{C}$ & $3.9436^{\mathrm{nb}}$ & $0.2523^{n}$ & $0.6500^{n}$ \\
\hline & $80^{\circ} \mathrm{C}$ & $3.7016^{b}$ & $0.2293^{\prime \prime}$ & $0.6083^{n}$ \\
\hline & $100^{\circ 1} \mathrm{C}$ & $3.0934^{\circ}$ & $0.2134^{\circ}$ & $0.56007^{11}$ \\
\hline & $120^{\circ} \mathrm{C}$ & $2.9495^{\circ}$ & $0.2171^{\mathrm{c}}$ & $0.5333^{\circ}$ \\
\hline & Wet-milled paste & $4.1006^{n}$ & $0.2661^{11}$ & $0.6333^{a}$ \\
\hline
\end{tabular}

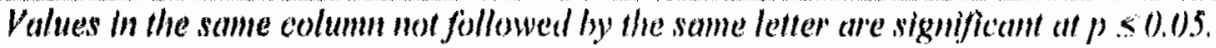

the same level. However, addition of other ingredients decrensed the llow behaviour index of the moin-moin samples prepared from the wetmilled cowpea paste, even to a value lower than that of moin-moin pastes prepared from cowpea nour.

Of all the plain moin-moin pastes, the $80^{\circ} \mathrm{C}$ samples had the highest flow consistency (b) value. This decreased toward 30 and $120^{\circ} \mathrm{C}$. This trend was similar when other ingredients were added. However, the moin-moin pastes prepared from wet milled cowpea with other ingredients had higher flow consistency value than for corresponding plain samples. The moin-moin prepared from the wet milled cowpea paste had about four times the flow consistency values of samples prepared with cowpea flours for the plain sample and when other ingredients were added. Moin-moin pastes obeyed

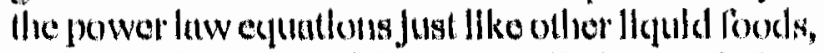
for example, 13\% and 16\% soymilk (Son and Sing, 1998).

\section{Typical flow behaviour of moin-moin pastes}

From the flow behaviour data obtained, it has been shown that as the shear rate of all the moinmoin pastes were increased, the shear stress increased, but the viscosity decreased. In addi- tion, the flow behaviour indices (n) of all the moin-moin pastes were greater than zero and less than 1.0, irrespective of the cowpea seed drying temperature or type of milling. According to Holdsworth (1971), this is typical of pscudoplastic flow behaviour. This was used in the study of rheological properties of gums by Uzomah and $\Lambda$ hiligwo (1995) and Son and Sing (1998)).

Many studies have shown that the flow behaviour of liquid foods can be used to characterise them and to determine the effect of processing on their components. Consequently, the change in the viscosity of liquid foods especially those containing protein and starch have been used to determine the effect of various treatments on their components (Evans and Ilaisman, 1979, and Lee and Rlın, 1977).

\section{Texture proflle and mechanlcal properties of moin-moin gel}

A typical force-deformation curve of steamed moin-moin gel samples is shown in Figure 3 and the texture profile parameters and mechanical properties are given in Table 3. The hardness and cohesiveness of both the plain moin-moin samples and those containing additional ingredients decreased from 30 to $120^{\circ} \mathrm{C}$. These decreases prob- 
ably resulted from the alterations of the protein and starch because of the effect of hent during drying (Einwere, et al, 1998). There were differences between the elastic modulus of the moinmoin smmples prepared firm the diflerent flours but they were not significant, showing that the mente of deformation of the platin moln-moln samples were similar.

The hardness of the plain moin-moin samples prepared from wet-milled cowpeas was higher than those prepared from cowpea flour, although they were significant only for 80 to $120^{\circ} \mathrm{C}$ samples. The cohesiveness of the moin-moin prepared with wet milled paste was similar to the $30^{\prime \prime} \mathrm{C}$ sample but significantly higher than the 60 to $120^{\circ} \mathrm{C}$ moin-moin samples.

When other ingredients were added to the moin-moin samples, the values for the hardness and elastic modulus, generally decreased but cohesiveness reminned nlmust at the stmme lovel. 'This is the reverse of the observalion in the viscosity of the raw paste, where addition of ingredients increased viscosily.

According to ()ssni el al. (1987), the oil added to the moin-moin is primarily responsible for reduced hardness. When other ingredients were added to the moin-moin, there seemed to be a general trend where the gel hardness, cohesiveness and elastic modulus decreased with increase in cowpea seed drying temperature. The effect was significant from $80^{\circ} \mathrm{C}$ for hardness and cohesiveness and elastic modulus from $100^{\circ} \mathrm{C}$. Despite the differences in the rheological characterislics of the moin-moin paste prepared from wetmilled paste and flours from 30 to $80^{\circ} \mathrm{C}$ pre-treatment, they were observed in earlier study to have desirnble sensory properties. They were also very acceptable to taste panellists (Enwere, 1985).

\section{Conclusion}

This study has shown that drying wetted cowpea seeds at temperatures above $80^{\circ} \mathrm{C}$ adversely affected some rheological properties of the resulting flour. The moin-moin pastes and gels prepared from the 100 and $120^{\circ} \mathrm{C}$ drying operations were generally different from those between 30 and $80^{\prime \prime} \mathrm{C}$ samples although in some cases, significant differences oceurred at $80^{\circ} \mathrm{C}$. Wet-milled cowpea seed produced moin-moin paste that was thicker than those from flours and the correspondling, moin. moln gels were larder than those gels prepared from flours. The cowpen seeds to be used for llour inlended for moln-moln preparation should, herefore, not be dried at temperatures above $80^{\circ} \mathrm{C}$ since some adverse effects began to occur from the higher temperature.

Acknowledgement

This work was supported the University of Nigeria, the State and Ilatch liunds allocated to University of Georgia, and the Bean/Cowpen Collaborative Research Support Programme (CRSP') funded by US Agency for International Developinent. 'The assistance of the following members of CRSP is acknowledged: K. H. McWatters, R. D. Phillips, M. S. Chinnann, L. Brtunch and P. O. Ngoddy.

\section{References}

Houme, M. C. and Comstock. S. II. (1981). Ififect of degree of compression on texture prolile parameters. J. Text. Stud. 12:201 -216 .

Dovlo, L. B., Willians, C. li., and \%oaka, I. (1976). Conpeas: Home Preparation and Use in West Africa. IDRC, Ottawa Canada.

Enwere, N. J. (1985). Effect of tempering and drying on the functional propertics and performance of cowpen flour during akara and moin-moin preparations. M.Sc. Thesis, Department of Food Science and Technology, University of Nigeria, Nsukka.

Enwere, N. J. (1998). Foods of Plant Origin. Afro-Orbis Publications Ltd., Nsukka. pp. $46-47$.

Enwere, N. J. Hung, Y. C. and Ngoddy P. O. (1990) Texture and microstructure of African yam bean (Sphenostylis stenocarpa) products. J. Text. Stud. 21(4): 377- 393

Enwere, N. J., McWatters, K. H. and Philips, R. 
D. (1998). Effect of processing on some properties of cowpea (Vigna unguiculara) seed, protein, starch, flour and akara. Intl. J. Food Sci. Nutr. 49: $365-373$.

Evans, I. D. and Haisman, D. R. (1979). Rheology of gelatinised starch suspensions. $J$. Text stud. 10: 347 -

Holdswoth, S. D. (1971), Applicability of rheological models to interpretation of llow and processing behaviour of fluid products. J. Text Stud. 2: 393-441.

Lee, C. H. and Rha C. K. (1977). Thickening of soy protein suspension with calcium $J$. Text stud. 1: 441 -

McWatters, K. 11. (1983). Compositional, physical and sensory characteristics of akara processed from cowpea paste and Nigerian cowpea flour. Cereal Chem: $60333-$ 336

McWatters K. H. and Brantley, B. B.. (1982). Characteristics of akara prepared from cowpea paste and meal. Food Technol. 36 (1): $66-68$.

Onweluzo, J. C., Obanu, Z. A. and Onuoha, K. C. (1994). Viscosity studies on the flour of some lesser-known tropical legumes. Nigerian Food J. 12, 1-10.

Purseglove, J. W. (1991). Tropical Crops: Docotyledons: Longman Scientific and Technical and John Wiley and Sons, Harlow, New York.

SAS (1985) User's Guide, Basic, Version 5 ed. Statistical Analysis System Institute, Inc., Cary N. C.

Son, S. M. and Singh, R. K. (1998). Rheological behaviour of aseptically processed soybean milk under turbulent llow conditions. Intl. J. Food Properties 1(1): 57-70.

Uzomah, A. and Ahiligwo, R. N. (1995). Rheological properties and functional potentials of achi (Brachystagea eurycoma) seed gum and ogbono (Irvingia gabonensis). Nigerian Food J. 12, 1-10. 